\title{
Doppler radar rainfall prediction and gauge data
}

\author{
Jesse W. Lansford ${ }^{1 *}$, Tyson H. Walsh'1 , T. V. Hromadka II and P. Rao ${ }^{2}$
}

\begin{abstract}
Objective: The data herein represents multiple gauge sets and multiple radar sites of like-type Doppler data sets combined to produce populations of ordered pairs. Publications spanning decades yet specific to Doppler radar sites contain graphs of data pairs of Doppler radar precipitation estimates versus rain gauge precipitation readings.

Data description: Taken from multiple sources, the data set represents several radar sites and rain gauge sites combined for 8830 data points. The data is relevant in various applications of hydrometeorology and engineering as well as weather forecasting. Further, the importance of accuracy in radar and precipitation estimates continues to increase, necessitating the incorporation of as much data as possible.
\end{abstract}

Keywords: Hydrometeorology, Engineering, Floodplain management, Weather forecasting

\section{Objective}

Prediction of rainfall using Doppler technology relies on synthesizing the signal information that the radars receive back from the atmosphere. Processing this signal information yields a rainfall estimate relying on relationships between statistical regression equations and several other parameters. Herein we present the ordered data for both Doppler radar precipitation estimates with associated gauge precipitation estimates pulled from ten referenced publications. Researchers may use these rainfall estimates for study purposes by comparing the accuracy of the Doppler radar estimated precipitation with the actual comparative gauge data. An indication of the estimation error can be determined by comparing the frequency distribution of the source data against the regression equation predictors obtained from the Doppler radar estimates.

This data is relevant to other researchers involved in investigating the association of Doppler radar data and gauge precipitation estimate relationships [1].

\footnotetext{
*Correspondence: jesse.lansford@westpoint.edu

${ }^{1}$ Department of Mathematics, United States Military Academy, West

Point, NY, USA

Full list of author information is available at the end of the article
}

\section{Data description}

Datasets generated and/or analyzed during the current study are available in the figshare repository: https://doi. org/10.6084/m9.figshare.11811675.v1 [2].

Published literature contains data in the form of scatter plots and tables [3-12]. The data compares Doppler radar derived rainfall estimates with observed local gauge values, spread across storms and geographical domains with the majority categorized via total storm accumulation. Pulling from each reference, digitizing software reads graphs and tabulates data for later concatenating. Specifically, the plot digitizer (http:// plotdigitizer.sourceforge.net/), is a Java tool that digitizes data points from scanned plots. Note that the data used for analysis is not raw data; it is the end data obtained by the respective authors after applying standard corrections (if any) to the radar reflectivity and other parameters. The gauge data are also the final data as recorded by the gauges at the respective locations. There is no need for additional corrections or processing for the published data in the cited references. The data used in the referenced analysis [1] are from the original, cited manuscripts. Assume that the displayed data points relating to the correlation between Doppler-Radar readings versus measured precipitation, as

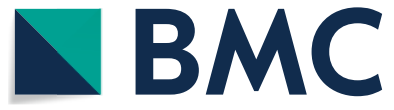

(c) The Author(s) 2020. This article is licensed under a Creative Commons Attribution 4.0 International License, which permits use, sharing, adaptation, distribution and reproduction in any medium or format, as long as you give appropriate credit to the original author(s) and the source, provide a link to the Creative Commons licence, and indicate if changes were made. The images or other third party material in this article are included in the article's Creative Commons licence, unless indicated otherwise in a credit line to the material. If material is not included in the article's Creative Commons licence and your intended use is not permitted by statutory regulation or exceeds the permitted use, you will need to obtain permission directly from the copyright holder. To view a copy of this licence, visit http://creativeco mmons.org/licenses/by/4.0/. The Creative Commons Public Domain Dedication waiver (http://creativecommons.org/publicdomain/ zero/1.0/) applies to the data made available in this article, unless otherwise stated in a credit line to the data. 
Table 1 Overview of data files/data sets

\begin{tabular}{llll}
\hline Label & Name of data file/data set & File types (file extension) & Data repository and identifier (DOI or accession number) \\
\hline Data file 1 & DopplerWeatherData & Comma Separated Values (.csv) & https://doi.org/10.6084/m9.figshare.11811675.v1 [2] \\
\hline
\end{tabular}

shown in the various figures of the published papers shown in the references, are adequately processed and suitable for further analysis. Without the actual source data, the processed data supplied by the respective papers' authors or digitizing the data directly from the papers used, populated the ordered pairs in the presented data set. Assume that standard procedures for processing the source data were used for the various papers assembled from the literature. These standard procedures as detailed by the respective authors relate to the geographical location of radar and gauge. Similarly, the rain-gauge data are obtained from the papers' authors or by digitizing the point data displayed in the respective paper's diagrams and figures.

The data file (Table 1) comprises two columns of rainfall data; Gauge and Radar. Gauge consists of rainfall values in millimeters given by the recording gauge following the precipitation event. Radar consists of estimated rainfall values in millimeters given by the Doppler radar estimates prior to the precipitation event. Concatenating these two columns results in 8830 ordered pairs.

We did not seek other information such as measurement site location and collection time. This paper attempts to develop a correlation between published, open literature versus possible uncertainty in using such information. Further, we did not seek underpinnings of how published correlations between measured information and gage data were formulated. Rather, we focus on the data as published and what generalizations can be made about Doppler-Radar and Dual Doppler-Radar versus uncertainty in predicting measured precipitation on the ground. Although true that an indication of estimation error can be determined by comparing the frequency distribution of the source data against the regression equation predictors obtained from the Doppler radar estimates, this research effort does not move towards resolving such factors in order to be able to assess the value of direct use of published information.

\section{Limitations}

Due to the replacement of Doppler radars with dualpolarization radars, there is currently no more data being collected for additional analysis.
Acknowledgements

Not applicable.

\section{Authors' contributions}

TVH and PR collected the data. THW and JWL wrote the manuscript describing the data. All authors read and approved the final manuscript.

\section{Funding}

This research is funded by a research fund supporting Faculty in the Mathematics Department at the United States Military Academy.

\section{Availability of data materials}

The datasets generated during and/or analysed during the current study are available in the figshare repository: https://doi.org/10.6084/m9.figshare.11811 675.v1 [2].

\section{Ethics approval and consent to participate}

Not applicable.

Consent for publication

Not applicable.

\section{Competing interests}

The authors declare that they have no competing interests.

\section{Author details}

${ }^{1}$ Department of Mathematics, United States Military Academy, West Point, NY, USA. ${ }^{2}$ Department of Civil and Environmental Engineering, California State University, Fullerton, CA, USA.

Received: 20 March 2020 Accepted: 28 September 2020

Published online: 14 October 2020

\section{References}

1. Hromadka TV II, Rao P, Walsh TH. Assessment of uncertainty in Doppler Radar estimated precipitation. Am Inst Hydrol. 2018;34(2):4-7.

2. Jesse, L., Walsh, T., Hromadka, T. \& Rao, P. Doppler weather data. figshare 2020, https://doi.org/10.6084/m9.figshare.11811675.v1.

3. Baeck ML, Smith JA. Rainfall estimation by the WSR-88D for heavy rainfall events. Weather Forecast. 1998;13(2):416-36.

4. Gourley JJ, Maddox RA, Howard KW, Burgess DW. An exploratory multisensor technique for quantitative estimation of stratiform rainfall. J Hydrometeorol. 2002;3(2):166-80.

5. Fulton, R. (2000). Hydrometeorology Group's Projects and Plans for Improving WSR-88D Rainfall Algorithms and Products, Retrieved from http://www.nws.noaa.gov/oh/hrl/papers/2000mou_pdf/chapter1.pdf.

6. Jayakrishnan $\mathrm{R}$, Srinivasan $\mathrm{R}$, Arnold J. Comparison of raingage and WSR-88D Stage III precipitation data over the Texas-Gulf basin. J Hydrol. 2004;292(1-4):135-52.

7. Klazura GE, Thomale JM, Kelly DS, Jendrowski P. A comparison of NEXRAD WSR-88D radar estimates of rain accumulation with gauge measurements for high- and low-reflectivity horizontal gradient precipitation events. J Atmos Ocean Technol. 1999;16(11):1842-50.

8. Morin E, Maddox RA, Goodrich DC, Sorooshian S. RadarZ-RRelationship for summer monsoon storms in Arizona. Weather Forecast. 2005;20(4):672-9.

9. Seo D, Breidenbach JP. Real-time correction of spatially nonuniform bias in radar rainfall data using rain gauge measurements. J Hydrometeorol. 2002·3(2):93-111. 
10. Seo B, Dolan B, Krajewski WF, Rutledge SA, Petersen W. Comparison of single- and dual-polarization-based rainfall estimates using NEXRAD data for the NASA lowa Flood Studies Project. J Hydrometeorol. 2015;16(4):1658-75.

11. Cunha LK, Smith JA, Baeck ML, Krajewski WF. An early performance evaluation of the NEXRAD dual-polarization radar rainfall estimates for urban flood applications. Weather Forecast. 2013;28(6):1478-97.

12. Seo B, Krajewski WF. Scale dependence of radar rainfall uncertainty: initial evaluation of NEXRAD's new super-resolution data for hydrologic applications. J Hydrometeorol. 2010;11(5):1191-8.

\section{Publisher's Note}

Springer Nature remains neutral with regard to jurisdictional claims in published maps and institutional affiliations.
Ready to submit your research? Choose BMC and benefit from:

- fast, convenient online submission

- thorough peer review by experienced researchers in your field

- rapid publication on acceptance

- support for research data, including large and complex data types

- gold Open Access which fosters wider collaboration and increased citations

- maximum visibility for your research: over $100 \mathrm{M}$ website views per year

At BMC, research is always in progress.

Learn more biomedcentral.com/submissions 